\title{
URBANISATION PROCESSES IN PUSZCZA ZIELONKA LANDSCAPE PARK IN POLAND - AND ITS BUFFER ZONE IN THE CONTEXT OF PROTECTION OF NATURAL STRUCTURES
}

\author{
WILKANIEC, A. ${ }^{*}{ }^{*}$ - GAŁECKA-DROZDA, A. ${ }^{1}$ - RASZEJA, E. ${ }^{2}-$ SZCZEPAŃSKA, M. ${ }^{3}$ \\ ${ }^{1}$ Department of Landscape Architecture, Poznań University of Life Sciences \\ Dabrowskiego 159, 60-594 Poznań, Poland \\ (e-mail:agnieszka.wilkaniec@up.poznan.pl; anna.galecka@up.poznan.pl) \\ ${ }^{2}$ Department of Architecture and Urban Planning, Faculty of Architecture and Design, \\ University of the Arts in Poznań, 29 Aleje Marcinkowskiego, 60-967 Poznań, Poland \\ (e-mail: elzbieta.raszeja@uap.edu.pl) \\ ${ }^{3}$ Faculty of Socio-Economic Geography and Spatial Management, Adam Mickiewicz \\ University in Poznań, Krygowskiego 10, 61-680 Poznań, Poland \\ (e-mail: szmagda@amu.edu.pl) \\ *Corresponding author \\ e-mail: agnieszka.wilkaniec@up.poznan.pl; phone: +48-618-487-990; fax: +48-618-487-959
}

(Received $12^{\text {th }}$ Jun 2019; accepted $11^{\text {th }}$ Oct 2019)

\begin{abstract}
Puszcza Zielonka Landscape Park (PZLP), located in western Poland is an area under the constant pressure of urbanization processes occurring in the zone of influence of the Poznan urban agglomeration. The park was established in 1993. The protected area is surrounded by built-up areas, which interrupt the continuity of wildlife corridors. The park and its buffer zone are located in six communes, which have their own spatial policies. The aim of the article was to determine changes in the trends, scale and rate of investments in the park and its buffer zone, expressed by changes in the land cover and use, which have taken place since the establishment of the park. These changes were considered important factors affecting the state of protected natural values and defining the effectiveness of protective instruments. The study included an analysis of the spatial policy of the communes expressed in Study of the Conditions and Directions of the Spatial Management (SCDSM) and its compliance with the Park protection trends indicated in the Protection Plan. The analyses were carried out with GIS tools. The results showed conflicts between the intended changes in land development expressed by local governments and the park protection objectives.
\end{abstract}

Keywords: nature conservation, land use, cohesion policy, spatial planning, ecological network

\section{Introduction}

According to the Nature Conservation Act (2004), a landscape park is a largescale form of nature conservation created for natural, historical, cultural and scenic values so as to preserve and popularise them with respect to sustainable development. 131 landscape parks have been established in Poland. They occupy a total area of about 2.61 million ha, i.e. $8.3 \%$ of the area of Poland and $2 \%$ of the protected area system. So far 13 landscape parks have been established in Greater Poland (Wielkopolska). They occupy a total area of $179,870.60$ ha. A landscape park is a form of protection of natural and scenic values which does not involve restrictive protective provisions. Business activities are allowed in landscape parks and their buffer zones. They are only partly limited by specific regulations. This is in line with the concept of active protection, but simultaneously, it may cause different conflicts and threats. The continuous loss of 
biodiversity and unfavourable changes in the natural environment, which are globally observed, are mostly caused by human activities such as intensive agricultural production, urbanization and infrastructure development, which lead to overexploitation of natural resources and degradation of the environment. These problems also affect particularly valuable areas, including protected areas. The need to combine the objectives of nature conservation and environment protection with the objectives resulting from the need for socioeconomic development and the needs of local communities is a significant challenge all over the world (Dimitrakopoulos et al., 2010; Bicknell et al., 2017; Lopez-Bao et al., 2017; Weaver and Lawton, 2017; Atmis, 2018).

Urbanization is thought to be the second (after agricultural production) most unfavourable factor exerting pressure on natural ecosystems, but it has the most degrading and the longest-lasting effects (Treby and Castley, 2016). It may cause the loss, fragmentation or isolation of valuable ecosystems (including forests) (Bradshaw, 2012) and the declineing ecological stability (Muchová and Tárníková, 2018) the loss of open spaces (including agricultural areas) as well as increased environmental pollution, especially water (Maheshwari and Bristow, 2016), air and soil (Zhang, 2016). It may also limit biodiversity, threatening numerous species of plants and animals (Hamer and McDonnell, 2008; Border et al., 2017). The dynamic development of cities increases the urbanisation pressure exerted on protected areas (McDonald et al., 2009).

Changes induced by urbanization and manifested by the development of buildings in Puszcza Zielonka Landscape Park, located in Greater Poland (Wielkopolska) near the city of Poznań and, above all, in its buffer zone were the subject of research presented in this article. These changes are considered a significant factor affecting the state of protected natural values and determining the effectiveness of protective instruments, especially those related with spatial planning. The aim of the original research was to determine changes in the trends, scale and rate of investments in the park and its buffer zone, expressed by changes in the land cover and use, which have taken place since the establishment of the park. The study included an analysis of the spatial policy of the communes expressed in Study of the Conditions and Directions of the Spatial Management of a Commune (hereinafter SCDSM) and its compliance with the Park protection trends indicated in the Protection Plan.

\section{Study area and methods}

Puszcza Zielonka Landscape Park, established in 1993, hereinafter referred to as PZLP, is located about $30 \mathrm{~km}$ northeast of the city of Poznan (Fig. 1). There is about $120.4 \mathrm{~km}^{2}$ of protected area, which is mostly covered by forests. There are a few villages and hamlets located within the boundaries of PZLP (Kamińsko, Pławno, Tuczno, Zielonka, Głęboczek, Łopuchówko, Gać, Dzwonowo, Dąbrówka Kościelna). Apart from buildings, there are some small meadows, wastelands and cultivated lands in these places. The terrain also includes numerous ribbon lakes, which make the park particularly attractive to tourists. There are often recreational buildings near the lakes. They are mostly concentrated on Lake Kołatkowskie and Lake Tuczno in the village of Tuczno, and on Lake Miejskie in the village of Kamińsko.

The park is surrounded by a buffer zone, which occupies an area of about $97.8 \mathrm{~km}^{2}$. The buffer zone terrain mostly includes arable lands, enclosures and suburban singlefamily buildings. The biggest settlements located in the PZLP buffer zone are: Kicin, Owińska, Bolechówko, Rakownia and Boduszewo. 
The park area is located in the communes of Czerwonak, Skoki, Murowana Goślina, Kiszkowo, and Pobiedziska (part of the buffer zone is also located in the commune of Swarzędz) and in the counties of Poznań, Wagrowiec and Gniezno. The largest part of PZLP is located in the commune of Murowana Goślina and occupies an area of nearly 6,200 ha. The smallest part of the park is located in the commune of Kiszkowo, with about 360 ha of protected areas. More than a half of the buffer zone area is located in the communes of Czerwonak and Pobiedziska (2,870 ha and 2,500 ha, respectively). The smallest part of the buffer zone area is in the commune of Skoki - 870 ha (the author's calculation).

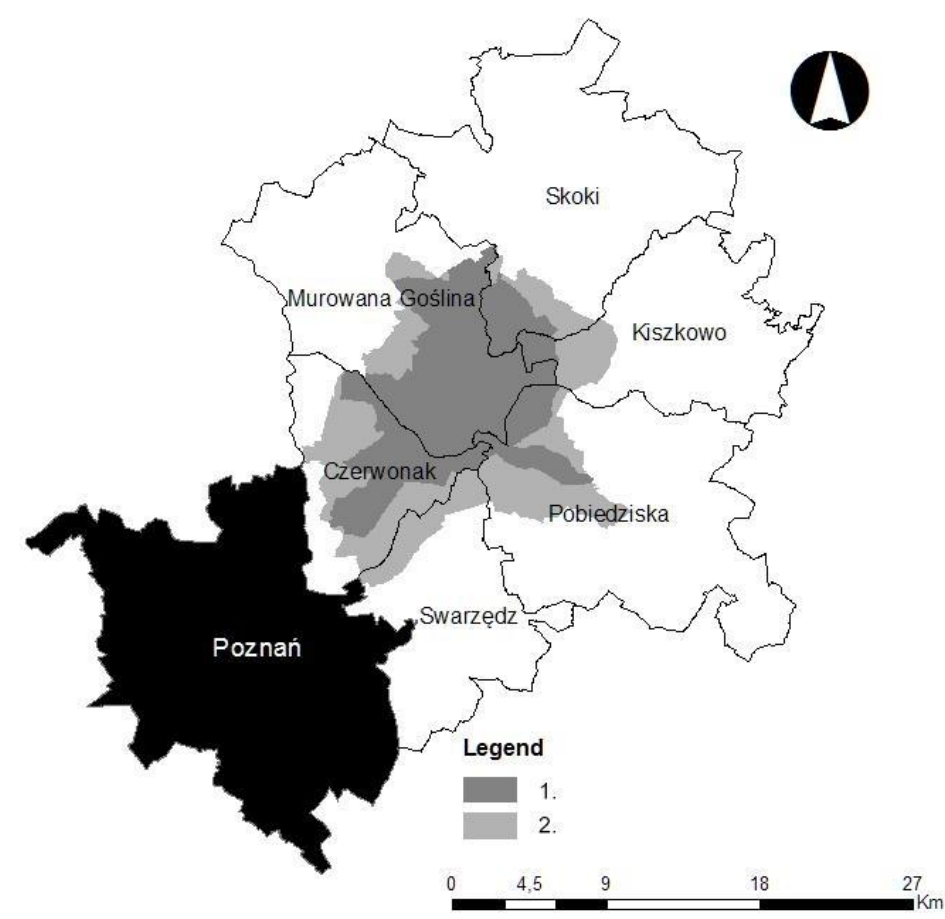

Figure 1. The administrative location of Puszcza Zielonka Landscape Park with its buffer zone: 1. Puszcza Zielonka Landscape Park, 2. The buffer zone of Puszcza Zielonka Landscape Park

The ArcGIS 10.5.1 version was used to investigate changes in the terrain occupied by the park and buffer zone. The rate and scale of transformations was observed at three chosen momens: first - in the past (1989); second - the current state (2017) and third in the future, showing the changes predicted on the basis of planning documents. The first interval refers to the period before 1993, when the park was established. Data for this period were obtained by the digitalization of archival topographic maps scaled 1:25,000, which were imported by the WMS service. The maps were made between 1962 and 1989. Presented maps and data show distribution of the different land use types. We assumed a small scale of changes that took place at that time due to investment limitations before the transformation of the political system in Poland in 1989. The second time interval covers the changes which have taken place since the park was established and which were registered on the basis of current (2017) orthophoto maps (geoportal.gov.pl). Presented data and maps show distribution of the different land use types in about 2017 year. Next, the Study of the Conditions and 
Directions of the Spatial Management of individual communes located in the Park and its buffer zone were studied to make a forecast of possible changes in the land cover and use. Local Spatial Management Plans were not taken into account due to the fact that these documents covered only a small part of the area under study.

As there were different thematic layers in the SCDSM of individual communes, it was necessary to simplify the provisions in them and adapt them to the terrain typology assumed in this article so as to identify and make a synthetic record of changes. The following 9 types of land cover were distinguished: (1) forests, (2) trees (mid-field afforestations, wastelands overgrown with trees, lanes of trees along watercourses), (3) surface waters, (4) meadows and pastures, (5) arable land, (6) permanent crops, (7) residential, recreational and service buildings, (8) storage and industrial areas, (9) roads. Then, the area was measured according to the aforementioned typology, allowing for the assumed research periods. The rate of dynamics of variation in the land cover was calculated according to the following formula developed by the authors (GałeckaDrozda et al., 2019), where the data for 1989 were assumed as the starting point (Eq. l).

$$
R_{d v l c}=\left(\frac{\text { Ca or } F a}{I a} * 100 \%\right)-100 \%
$$

where:

Rdvlc - the rate of dynamics of variation in the land cover [\%];

$\mathrm{Ca}$ - the current area [ha] (data from 2017);

$\mathrm{Fa}$ - the forecast area [ha] (based on Studies of Conditions and Directions of the Spatial Menagement);

Ia - the input area [ha] (areas used as reference for other periods under analysis, data from 1989).

The results of investigations made at the three time intervals were presented in a standardised graphic form, which enabled a comparison of changes in the land cover and use during the entire research period. Changes in the park and its buffer zone were analysed separately. The research also included a comparative analysis of the spatial policies in individual communes based on the provisions included in SCDSM. Next, the provisions were compared with the recommendations included in the PZLP Protection Plan.

\section{Content of Puszcza Zielonka Landscape Park Protection Plan}

Following Art. 19 Para. 6 of the Nature Conservation Act of 16 April 2004 and in order to stop unfavourable processes occurring in PZLP the Park authorities prepared the Park Protection Plan (Puszcza Zielonka Landscape Park Protection Plan, 2005). 8 functional and landscape zones were identified in PZLP and its buffer zone. Orders and prohibitions regarding the conservation of resources were formulated for 5 zones, located within the Park. Recommendations concerning the economic use and space management were made for 3 zones located in the buffer zone.

Tasks, orders and prohibitions were formulated within the zones. Their aim was to conserve nature and protect landscape, allowing for sustainable development, without complete exclusion of business activity from the PZLP area. Recommendations related to the functioning of the zones should be transferred to the planning documents of municipalities in the Park. The protection plan included 37 arrangements concerning the elimination or limitation of external threats, which were included in the study of the 
conditions and directions of the spatial management in communes, local spatial management plans and the voivodeship spatial development plan. Most provisions in the Park Protection Plan concern the limitation of urbanization pressure in PZLP and its buffer zone, for example by leaving undeveloped strips of land along the forest border and lake shores, by avoiding the scattering of buildings and locating them in areas without the infrastructure, by not separating new building plots in particularly valuable areas, including river valleys.

\section{Results}

Analysis of spatial policy of communes based on Study of the Conditions and Directions of the Spatial Management

The SCDSM of the communes located in PZLP and its buffer zone include declarations to protect the values due to which the park was established. However, the main goals of the spatial policy of communes are not always consistent with the objectives of PZLP protection, although all the SCDSM that were made after the Park Protection Plan refer to these documents. The functional and spatial zones and recommendations for them were transferred directly from the Park Protection Plan to the SCDSMof Murowana Goślina, Skoki and Swarzędz. The plans also include provisions which are beneficial to the Park protection. These provisions recommend the concentration rather than dispersion of buildings (Study of the Conditions and Directions of the Spatial Management of the Commune of Pobiedziska, 2011; Study of the Conditions and Directions of the Spatial Management of the Commune of Kiszkowo, 2012; Study of the Conditions and Directions of the Spatial Management of the Commune of Murowana Goślina, 2012), their location in places with adequate infrastructure (Study of the Conditions and Directions of the Spatial Management of the Commune of Pobiedziska, 2011), the will to inhibit space and environment degradation caused by uncontrolled development of holiday and residential buildings (Study of the Conditions and Directions of the Spatial Management of the Commune of Murowana Goślina, 2012). However, this did not prevent the provisions which allowed enlargement of built-up areas in the Park and the buffer zone. These areas became larger in all of the aforementioned communes, but to a different extent. In some communes the enlargement of built-up areas written in the SCDSM was moderate in relation to the areas belonging to the Park, whereas intensive building development was planned in areas of lower natural and scenic value, e.g. in the communes of Skoki, Swarzędz, and Czerwonak (including the repealed SCDSM of the Spatial Management (2010)).

During the period under study the commune of Czerwonak used the SCDSMadopted in 2000 and 2010 (Study of the Conditions and Directions of the Spatial Management of the Commune of Czerwonak, 2000, 2010). However, the sentence passed by the Provincial Administrative Court in Poznań in 2014 annulled the resolution concerning the newer variant of the document with more beneficial provisions referring to the protection of natural values in PZLP (Study of the Conditions and Directions of the Spatial Management of the Commune of Czerwonak, 2000, 2010).

\section{Analysis of changes in land cover in Park and its buffer zone}

At present more than $85 \%$ of the Puszcza Zielonka Landscape Park area is covered by forests (Table 1). 


$$
-702-
$$

Table 1. Variation of the land cover structure in the area of Puszcza Zielonka Landscape Park and its buffer zone

\begin{tabular}{|c|c|c|c|c|c|c|c|c|}
\hline $\begin{array}{l}\text { Type of } \\
\text { land cover }\end{array}$ & $\begin{array}{c}1989 \\
{[\mathrm{ha}]^{*}}\end{array}$ & $\begin{array}{c}\text { Share } \\
{[\%]}\end{array}$ & $\begin{array}{l}2017 \\
\text { [ha] }\end{array}$ & $\begin{array}{c}\text { Share } \\
{[\%]}\end{array}$ & $\begin{array}{c}\text { Indicator of } \\
\text { dynamics of } \\
\text { changes in } \\
\text { land cover } \\
1989-2017 \\
{[\%]} \\
\end{array}$ & \begin{tabular}{|l|} 
Forecast based on \\
Studies of the \\
Conditions and \\
Directions of the \\
Spatial \\
Management [ha] \\
\end{tabular} & $\begin{array}{c}\text { Share } \\
{[\%]}\end{array}$ & $\begin{array}{c}\text { Indicator of } \\
\text { dynamics of } \\
\text { predicted } \\
\text { changes in } \\
\text { land cover } \\
{[\%]} \\
\end{array}$ \\
\hline \multicolumn{9}{|c|}{ PZLP } \\
\hline Forests & $10,103.09$ & 83.94 & $10,316.08$ & 85.71 & 2.11 & $10,332.79$ & 85.85 & 2.27 \\
\hline $\begin{array}{c}\text { Areas with } \\
\text { trees }\end{array}$ & 7.38 & 0.06 & 7.38 & 0.06 & 0.00 & 6.79 & 0.06 & -7.99 \\
\hline $\begin{array}{c}\text { Surface } \\
\text { waters }\end{array}$ & 356.07 & 2.96 & 356.07 & 2.96 & 0.00 & 356.07 & 2.96 & 0.00 \\
\hline $\begin{array}{c}\text { Meadows } \\
\text { and pastures }\end{array}$ & 673.98 & 5.60 & 540.33 & 4.49 & -19.83 & 443.88 & 3.69 & -34.14 \\
\hline Arable land & 769.8 & 6.40 & 618.6 & 5.14 & -19.64 & 479.83 & 3.99 & -37.67 \\
\hline $\begin{array}{c}\text { Areas with } \\
\text { permanent } \\
\text { crops }\end{array}$ & 23.37 & 0.19 & 26.9 & 0.22 & 15.10 & 24.63 & 0.20 & 5.39 \\
\hline $\begin{array}{l}\text { Areas with } \\
\text { residential } \\
\text { buildings } \\
\text { and services }\end{array}$ & 94.89 & 0.79 & 162.45 & 1.35 & 71.20 & 383.82 & 3.19 & 304.49 \\
\hline $\begin{array}{c}\text { Storage and } \\
\text { industrial } \\
\text { areas }\end{array}$ & 4.07 & 0.03 & 4.84 & 0.04 & 18.92 & 4.84 & 0.04 & 18.92 \\
\hline Roads & 3.56 & $0.03 \%$ & 3.56 & 0.03 & 0.00 & 3.56 & 0.03 & 0.00 \\
\hline Total & 12036.21 & 100.00 & $12,036.21$ & 100.00 & - & $12,036.21$ & 100.00 & - \\
\hline \multicolumn{9}{|c|}{ Buffer zone } \\
\hline Forests & $2,140.07$ & 21.87 & $2,397.43$ & 24.50 & 12.03 & 2427.9 & 24.79 & 13.45 \\
\hline $\begin{array}{c}\text { Areas with } \\
\text { trees }\end{array}$ & 67.06 & 0.69 & 71.18 & 0.73 & 6.14 & 100.59 & 1.03 & 50.00 \\
\hline $\begin{array}{c}\text { Surface } \\
\text { waters }\end{array}$ & 137.43 & 1.40 & 137.43 & 1.40 & 0.00 & 136.43 & 1.39 & -0.73 \\
\hline $\begin{array}{c}\text { Meadows } \\
\text { and pastures }\end{array}$ & 922.34 & 9.43 & 1711.44 & 17.49 & 85.55 & 873.12 & 8.91 & -5.34 \\
\hline Arable land & $6,230.84$ & 63.68 & $4,937.32$ & 50.46 & -20.76 & 3678.83 & 37.56 & -40.96 \\
\hline $\begin{array}{c}\text { Areas with } \\
\text { permanent } \\
\text { crops }\end{array}$ & 43.79 & 0.45 & 46.9 & 0.48 & 7.10 & 19.65 & 0.20 & -55.13 \\
\hline $\begin{array}{l}\text { Areas with } \\
\text { residential } \\
\text { buildings } \\
\text { and services }\end{array}$ & 198.36 & 2.03 & 428.5 & 4.38 & 116.02 & 2454.73 & 25.06 & 1137.51 \\
\hline $\begin{array}{c}\text { Storage and } \\
\text { industrial } \\
\text { areas }\end{array}$ & 18.69 & 0.19 & 28.38 & 0.29 & 51.85 & 77.24 & 0.79 & 313.27 \\
\hline Roads & 25.54 & 0.26 & 25.54 & 0.26 & 0.00 & 25.54 & 0.26 & 0.00 \\
\hline Total & $9,784.12$ & 100.00 & $9,784.12$ & 100.00 & - & $9,794.03$ & 100.00 & - \\
\hline
\end{tabular}

* initial state - areas used as reference for other periods under analysis

Meadows, pastures and arable lands cover about $5 \%$ of the Park area. The share of built-up areas is small $-1.35 \%$ of the Park area, i.e. 162.5 ha. The comparison of the current state with the state before 1989 revealed slight changes. The forest area 
increased by over 200 ha (less than $2 \%$ of the total PZLP area), whereas the farmland area decreased (the area of meadows and pastures decreased by about 130 ha, whereas the area of plantations decreased by about $150 \mathrm{ha}$ ). At the same time, the built-up area increased by 68 ha (from $0.8 \%$ to $1.35 \%$ of the total area of the Park).

As results from the SCDSM of the communes belonging to the Park, the forest area will increase slightly, i.e. by about 16 ha, whereas the total farmland area may decrease by about 240 ha. The built-up area will increase by 221.4 ha (from $1.35 \%$ to $3.19 \%$ of the total PZLP area). The area of new buildings will significantly exceed the area that is currently occupied by buildings (Fig. 2). The areas of new investments are concentrated in Dąbrówka Kościelna (the commune of Kiszkowo) and in Tuczno (the commune of Pobiedziska). The areas of other building investments are scattered around the existing villages and hamlets in the Park.
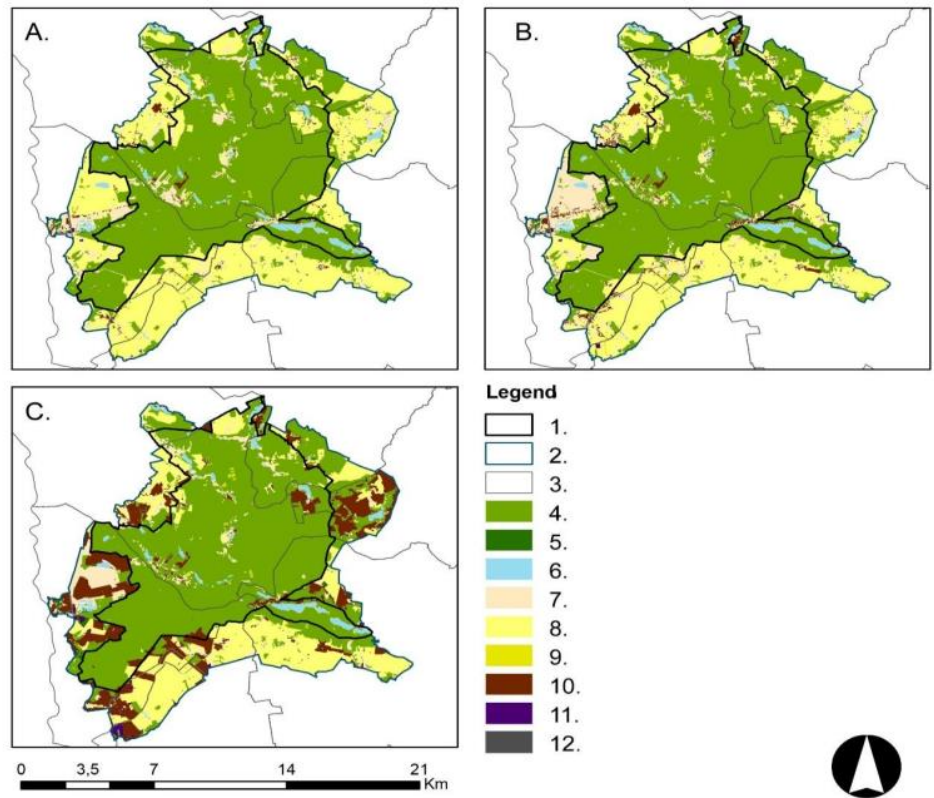

Figure 2. Changes in the land cover of Puszcza Zielonka Landscape Park and its buffer zone (A. Before 1989, B. Current state 2017; C. Forecast based on the Study of the Conditions and Directions of the Spatial Management; 1. Puszcza Zielonka Landscape Park, 2. Puszcza Zielonka Landscape Park buffer zone, 3. Commune boundaries, 4. Forests, 5. Trees, 6. Surface waters, 7. Meadows and pastures, 8. Arable land, 9. Permanent crops, 10. Residential, recreational and service buildings, 11. Storage and industrial areas, 12. roads)

At present the Park buffer zone is agricultural, as plantations, meadows and pastures occupy almost $70 \%$ of the area. The share of forests amounts to $25 \%$. Built-up areas occupy about. 430 ha, i.e. about $4.4 \%$ of the land cover. Since the end of the 1980 s the area of arable land has decreased by almost 1,300 ha. It was mostly transformed into meadows and pastures, the area of which has increased by almost 790 ha. These changes resulted from the progressive fallowing of arable land, which is a common phenomenon in areas under high investment pressure. The forest cover in the buffer zone has increased by nearly 260 ha (from about $22 \%$ to $25 \%$ of the total area). The share of built-up areas has increased by more than two times (by 230 ha, from $2 \%$ to $4.4 \%$ of the total area). According to the SCDSM, the area occupied by residential, recreational and service buildings may increase. It may ultimately cover $25 \%$ of the 
buffer zone, having increased by almost six times (by 2,026.23 ha). New building investments are planned in farmlands. The share of farmlands may decrease from $50.5 \%$ to $37.5 \%$ of the total buffer zone area, whereas the share of meadows and pastures may decrease from $17.5 \%$ to $9 \%$.

Residential, recreational and service development was the main focus of the analysis of changes in the use of space in the Park and its buffer zone in individual communes (Table 2). The greatest changes were observed or forecasted in these types of land cover. Differences in the farmland area were also significant, but they were closely related to changes in built-up areas, so they were not described in detail.

Table 2. Changes in the area of residential, recreational and service developments in PZLP and its buffer zone in individual communes

\begin{tabular}{|c|c|c|c|c|c|c|c|c|c|}
\hline Commune & $\begin{array}{c}\text { PZLP } \\
\text { area in } \\
\text { commune } \\
{[\text { ha] }}\end{array}$ & $\begin{array}{c}1989 \\
{[\text { ha]* }}\end{array}$ & $\begin{array}{c}\text { Share } \\
{[\%]}\end{array}$ & $\begin{array}{l}2017 \\
\text { [ha] }\end{array}$ & $\begin{array}{c}\text { Share } \\
{[\%]}\end{array}$ & $\begin{array}{c}\text { Indicator } \\
\text { of } \\
\text { dynamics } \\
\text { of changes } \\
\text { in land } \\
\text { cover 1989- } \\
2017 \text { [\%] }\end{array}$ & $\begin{array}{c}\text { Forecast based } \\
\text { on Study of the } \\
\text { Conditions and } \\
\text { Directions of } \\
\text { the Spatial } \\
\text { Management } \\
\text { [ha] }\end{array}$ & $\begin{array}{c}\text { Share } \\
{[\%]}\end{array}$ & $\begin{array}{c}\text { Indicator } \\
\text { of } \\
\text { dynamics } \\
\text { of } \\
\text { predicted } \\
\text { changes in } \\
\text { land cover } \\
{[\%]}\end{array}$ \\
\hline Czerwonak & 2849.65 & 5.07 & 0.18 & 13.16 & 0.46 & 159.57 & 82.67 & 2.90 & 1530.57 \\
\hline $\begin{array}{l}\text { Murowana } \\
\text { Goślina }\end{array}$ & 6199.33 & 59.43 & 0.96 & 89.51 & 1.44 & 50.61 & 111.25 & 1.79 & 87.20 \\
\hline Pobiedziska & 1527.72 & 21.80 & 1.43 & 48.35 & 3.16 & 121.79 & 69.91 & 4.58 & 220.69 \\
\hline Swarzędz & - & - & - & - & - & - & - & - & - \\
\hline Skoki & 1098.01 & 3.55 & 0.32 & 3.55 & 0.32 & 0.00 & 12.14 & 1.11 & 241.97 \\
\hline Kiszkowo & 361.49 & 5.04 & 1.39 & 7.87 & 2.18 & 56.15 & 107.85 & 29.83 & 2039.88 \\
\hline Commune & $\begin{array}{c}\text { PZLP } \\
\text { buffer } \\
\text { zone area } \\
\text { in } \\
\text { commune } \\
\text { [ha] }\end{array}$ & $\begin{array}{c}1989 \\
{[\text { ha] }}\end{array}$ & $\begin{array}{c}\text { Share } \\
{[\%]}\end{array}$ & $\begin{array}{l}2017 \\
\text { [ha] }\end{array}$ & $\begin{array}{c}\text { Share } \\
{[\%]}\end{array}$ & $\begin{array}{c}\text { Indicator } \\
\text { of } \\
\text { dynamics } \\
\text { of changes } \\
\text { in land } \\
\text { cover 1989- } \\
2017 \text { [\%] }\end{array}$ & $\begin{array}{c}\text { Forecast based } \\
\text { on Study of the } \\
\text { Conditions and } \\
\text { Directions of } \\
\text { the Spatial } \\
\text { Management } \\
\text { [ha] }\end{array}$ & $\begin{array}{c}\text { Share } \\
{[\%]}\end{array}$ & $\begin{array}{c}\text { Indicator } \\
\text { of } \\
\text { dynamics } \\
\text { of } \\
\text { predicted } \\
\text { changes in } \\
\text { land cover } \\
{[\%]}\end{array}$ \\
\hline Czerwonak & 2869.96 & 84.24 & 2.94 & 192.01 & 6.69 & 127.93 & 1169.13 & 40.74 & 1287.86 \\
\hline $\begin{array}{l}\text { Murowana } \\
\text { Goślina }\end{array}$ & 1172.54 & 47.33 & 4.04 & 90.17 & 7.69 & 90.51 & 232.24 & 19.81 & 390.68 \\
\hline Pobiedziska & 2488.35 & 29.43 & 1.18 & 69.64 & 2.80 & 136.63 & 232.80 & 9.36 & 691.03 \\
\hline Swarzędz & 1358.12 & 8.85 & 0.65 & 11.79 & 0.87 & 33.22 & 171.90 & 12.66 & 1842.37 \\
\hline Skoki & 873.31 & 12.46 & 1.43 & 38.55 & 4.41 & 209.39 & 104.00 & 11.91 & 734.67 \\
\hline Kiszkowo & 1062.64 & 16.03 & 1.51 & 26.34 & 2.48 & 64.32 & 544.66 & 51.26 & 3297.75 \\
\hline
\end{tabular}

* initial state - areas used as reference for other periods under analysis

The distribution of changes in the land cover (mostly the enlargement of developed areas) in individual communes in PZLP and its buffer zone was uneven. Since the late 1980s the most buildings have appeared in the communes of Poznan County: Murowana Goślina (increase by 30 ha), Pobiedziska (increase by 26.5 ha) and Czerwonak (increase by $8 \mathrm{ha}$ ). The analysis of changes in relation to the area of communes located in the Park shows that they were the least favourable in Pobiedziska, where $1.74 \%$ of the commune area belonging to the park was occupied by new buildings. In the communes of Murowana Goślina and Czerwonak the areas belonging to the park and occupied by new buildings amounted to $0.49 \%$ and $0.28 \%$, respectively. 
In the commune of Kiszkowo the areas with investments increased only by 3 ha. There was no change in the commune of Skoki. The increase in built-up areas in particular communes was correlated with their location in relation to Poznań. The changes were the smallest in the communes which were the most distant from the city limits.

According to the SCDSM, the biggest changes in built-up areas located in the Park can be expected in the commune of Kiszkowo, where the area of new investments may increase by nearly 100 ha, i.e. by about $45 \%$ of all newly built-up areas in PZLP. It is a very high increase because the area occupied by the Park in this commune is the smallest (almost a third of this area may be developed). According to the SCDSM of the Commune of Kiszkowo, large areas will be used for housing development and some areas will be used for tourist and recreational development. The development area in the commune of Czerwonak may increase by almost 70 ha (in comparison with Kiszkowo it is a slight increase, i.e. a fortieth of the commune area located in the Park). Also, according to the SCDSM of this commune, large areas were allocated for the development of 'tourist services' (understood as tourist and recreational services), but only some of them can be used for building development, including recreational buildings. The potential increase in the area of investments in the Park located in the communes of Murowana Goślina and Pobiedziska is very similar, i.e. over 21 ha. However, as far as the area of communes located in PZLP is concerned, the situation is much better in the commune of Murowana Goślina, where new developments may occupy $1 / 285$ of the commune area belonging to the Park, whereas in the commune of Pobiedziska it will be a 1/17 of the Park area. The smallest increase in the area of new developments can be expected in the commune of Skoki, i.e. about 8.5 ha, which is $1 / 127$ of the Park area. (Fig. 2).

The distribution of changes in individual communes in the Park buffer zone was different than in PZLP. Between 1989 and 2017 the largest amount of new developments was observed in the commune of Czerwonak (more than 100 ha), which was under the greatest influence of Poznań, and in the commune of Murowana Goślina (about $43 \mathrm{ha}$ ). In both communes it was an increase of about $3.7 \%$ of the area located in the buffer zone. In the commune of Skoki the increase amounted to about 3\% (the area of new developments increased by 26 ha). Surprisingly, during the period under analysis the smallest amount of building developments in the Park buffer zone was observed in the commune of Swarzędz (only $3 \mathrm{ha}$ ), which is also strongly influenced by Poznań. The analysis of SCDSMof the commune showed that the potential areas of building developments were planned at other locations.

The greatest changes in the area of building developments in the Park buffer zone are forecasted in the commune of Czerwonak, where according to the SCDSM, almost 1,000 ha of new investments can be expected, which amounts to more than $48 \%$ of all new development areas in PZLP and nearly a third of the commune area in the Park buffer zone. In view of the Park protection aims, the provisions of the SCDSM of the Commune of Kiszkowo are the least favourable, where the increase in the area of new buildings concerns almost half of this area (about 540 ha). The potential increase in building development areas in the communes of Murowana Goślina, Pobiedziska and Swarzędz is very similar and amounts to 142,163 and 160 ha, respectively. The Park buffer zone located in the communes of Murowana Goślina and Swarzędz occupies about a seventh of their areas, whereas in the commune of Pobiedziska it is a fifteenth of the area. The increase in development areas was the smallest in the buffer zone 
located in the commune of Skoki (similar to that for the PZLP area) and amounted to 65 ha, i.e. about a thirteenth of the commune area being the buffer zone of the Park.

\section{Discussion}

The rapid global urban development decreases the distance between urban and protected areas. McDonald et al. (2009) proved that in many regions it was shorter than $50 \mathrm{~km}$, so urban areas may significantly affect protected areas. Intensified urbanization is also noticeable in PZLP and the Park buffer zone, which are located closest to the city limits of Poznań. Agricultural landscape still prevails in the northeast of the Park buffer zone. On the other hand, urbanization is the strongest in the southern and western parts of the Park buffer zone, where it is manifested by progressive increase in built-up areas, as compared with the time when the Park was established, and its further development, as provided in the SCDSM.

The administrative conditions of the Park and its buffer zone do not favour the protection of natural and scenic values. This space is managed by six communes which implement their own spatial policies with different assumptions. Although they undertake many joint activities in the fields of tourism and water and wastewater management and they cooperate within the Puszcza Zielonka Intercommunal Union, but the planning activities of individual communes are not coordinated. In practice, the declared intentions to protect natural values turn out to be in opposition to specific provisions of SCDSM of these communes. In consequence, it may increase urbanization in the Park and its buffer zone, even in the zones that were designated in the Park Protection Plan for protection against urbanization pressure. From the point of view of the goals of PZLP protection, the commune of Murowana Goślina as well as the communes of Skoki, Pobiedziska and Czerwonak have the most favourable spatial policies concerning construction areas. The scale of the growth of new buildings in the commune of Kiszkowo is incomparable with other communes and it is inconsistent with the assumptions of PZLP protection.

On the other hand, the most favourable spatial policy of protection of the Park buffer zone is led by the communes of Pobiedziska, Skoki, Swarzędz and Murowana Goślina. According to the SCDSM, the largest increase in new building developments can be expected in the communes of Kiszkowo and Czerwonak. Geldmann et al. (2015) stressed the importance of monitoring the management of protected areas. The assessment of the effectiveness of protective activities enables evaluation of the strengths and weaknesses of this process and helps to improve it. It also applies to conservation activities implemented at the lowest communal level of spatial planning in Poland.

The creation of buffer zones is a commonly used method to protect valuable natural areas. Studies conducted by Lima and Ranieri (2018) in Brazil showed that protection plans usually set recommendations rather than detailed rules for the use of buffer zone resources. Apart from that, individual SCDSM were inconsistent as regards spatial development in buffer zones around protected areas. The results of this study indicate that the use of a buffer zone as an effective strategy of management of protected areas requires detailed arrangements between the managements of protected areas and local governments responsible for land use planning. Otherwise, the establishment of a buffer zone can only be a symbolic action, without any practical influence on the preservation of values and the functioning of the protected area. 
The author's original research led to the conclusion that the presence of the PZLP buffer zone did not always isolate the Park from unfavourable spatial phenomena because the spatial policies of individual communes located in PZLP and its buffer zone were not always consistent with the Park protection goals. It is particularly worrying that according to the SCDSM, the commune governments have allocated such a large area of protected land for building developments. Different approaches of the communes to the spatial policy concerning valuable natural areas might indicate that not all local governments are aware of the significance of the existing values and the consequences of their loss. It is beneficial for the Park protection that according to the Studies of the Conditions and Directions of the Spatial Management (e.g. of Czerwonak (2010), Swarzędz (2011), Skoki (2010)), the local governments have allocated urbanized zones or strips for building developments outside the protected area and its buffer zone, in other parts of the communes. A similar solution was used in SCDSM of the commune of Pobiedziska (2011). However, a significant increase in housing and recreational investments in the Park and its buffer zone shows that the commune authorities have not been consistent in the implementation of this goal. Urbanization pressure is a commonly observed phenomenon also in other protected area in Poland (Wycichowska, 2008; Warczewska and Mastalarska-Cetera, 2011; Krajewski, 2014). Grochowska (2015) noted in Walbrzych Sudets Landscape Park the dispersion of buildings beyond shaped settlement systems and investment pressure directed at the most attractive landscapes and the expansion of summer construction, which is a result of improperly conducted municipal spatial policy.

As results from the SCDSM of Czerwonak, the situation is not good for the Park protection. In 2010, the authorities attempted to adopt a new Study. However, the sentence passed by the Provincial Administrative Court in Poznan in 2014 annulled the resolution of the Commune Council. In the new version of the document, the area of building developments was smaller than in the previous version, especially in the 'Forest Strip' and 'Open Landscape Strip', which covered the area of PZLP and its buffer zone. In contrast to the previous version of the SCDSM, according to the new version, one of the landowners was deprived of the right to build up plots in the village of Annowo, so he decided to go to court. The aforementioned areas were found to have natural and scenic values and were to be protected as the Annowo Meadows Protected Landscape Area. The sentence passed by the Provincial Administrative Court in Poznan in 2013 annulled also the resolution of the Commune Council in the matter of Annowo Meadows Protected Landscape Area creation, passed in 2008 (Environmental Protection Plan, 2013).

It is important not only to protect the Park area, but also to develop its connections with neighbouring valuable natural and protected areas such as: Promno Landscape Park, Natura 2000 areas (the Mała Wełna River Valley near Kiszkowo PLB300006, Biedrusko PLH300001, Kiszkowo Ponds PLH30_27, Biedrusko PLH300001), Biedrusko Protected Landscape Area, Lednica Landscape Park. The development of an ecological network combining valuable habitats into a system and preventing their fragmentation is considered to be one of the essential and most effective ways to protect biodiversity and preserve the stability of ecosystems (Closset-Kopp et al., 2016; Gonzalez et al., 2017; Fardila et al., 2017; Yang et al., 2017; Fletcher et al., 2018). One of the trends in nature conservation is to develop large-scale spatial systems consisting of protected areas, which are supplemented and connected by surrounding areas (Shwartz et al., 2017). The isolation of protected areas from their surroundings by 
building developments, which may destroy the existing links with neighbouring valuable natural areas and prevent the creation of such links in the future, is a negative effect of the urbanization of the areas surrounding PZLP (Fig. 3).

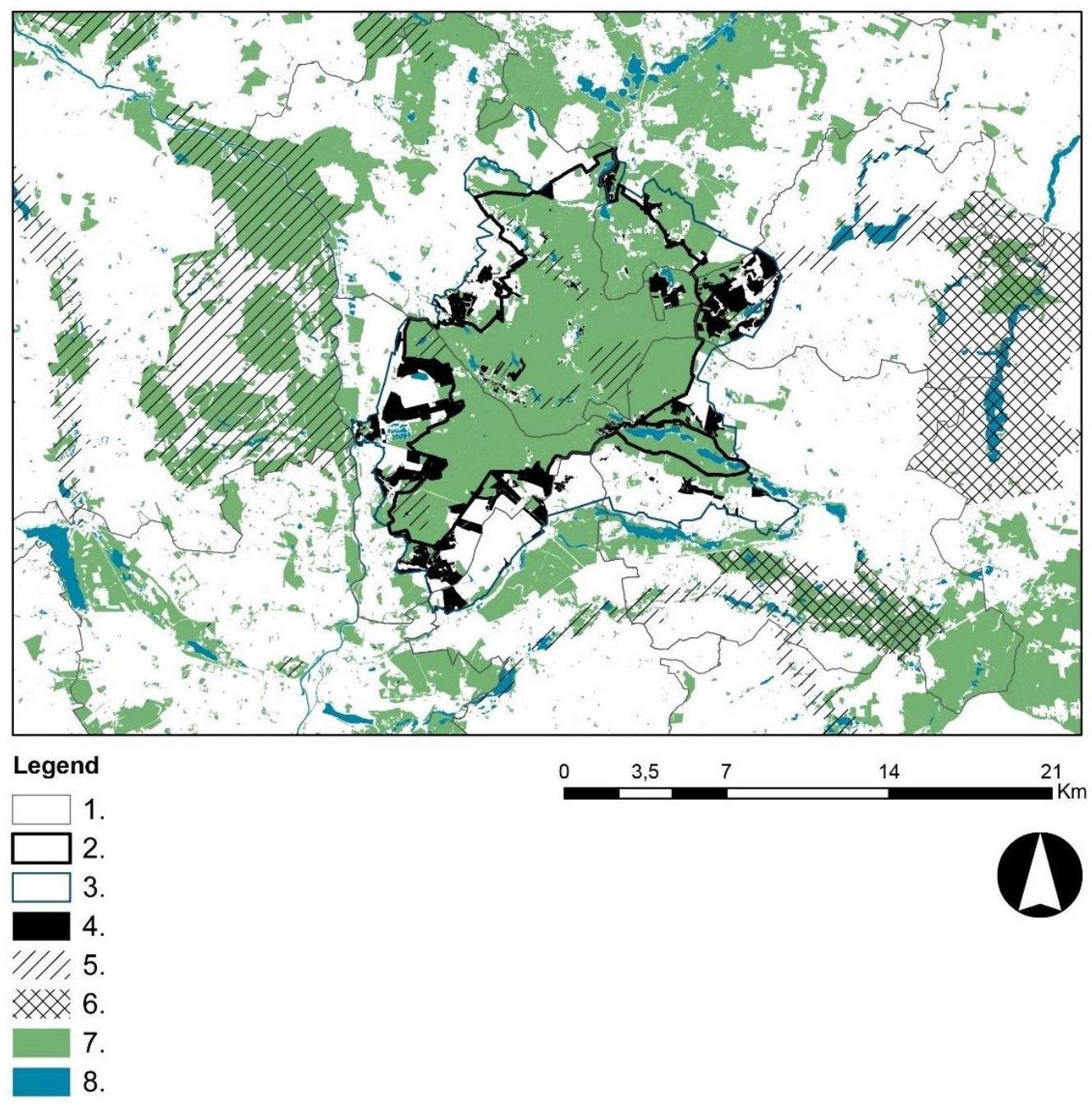

Figure 3. Areas for building developments in the Study of the Conditions and Directions of the Spatial Management of the communes vs. natural and protected areas in the surroundings of Puszcza Zielonka Landscape Park and its buffer zone (1. Commune boundaries, 2. Puszcza Zielonka Landscape Park, 3. Buffer zone, 4. Building development areas in the Park and its buffer zone according to the Study of the Conditions and Directions of the Spatial Management of the communes, 5. Natura 2000 areas, 6. Landscape parks, 7. Forests, 8. Open waters)

The problem particularly concerns the Park buffer zone, because it is subject to stronger urbanization pressure. As Xun et al. (2017) indicated, there is also an urgent need to protect or restore natural habitats located beyond directly protected areas so as to maintain the functional connection of habitat networks. In the past researchers indicated the problem of destruction of natural connections in PZLP by building developments, which enclosed forests with a ring (Raszka, 2010). Spatial planning tools give a possibility to create ecological networks (Szulczewska, 2004). However, as results from the research, not all communes are able and willing to use these tools. The 
problem of destruction of the continuity of valuable natural areas by building developments is most likely to affect the southwestern part of the Park buffer zone, which has links with the Warta River valley and the protected area on the other riverbank within the Biedrusko range. It is also likely to affect the eastern part, where Promno Landscape Park and Natura 2000 areas in the Wełna River valley are located near the Park buffer zone (Fig. 3).

\section{Conclusions}

Since the 1990s there have been changes in the land cover in Puszcza Zielonka Landscape Park. The forest area has increased slightly, the farmland area has decreased, and the share of built-up areas has increased. At the same time, there have been changes in the PZLP buffer zone. The area of arable land has decreased, the area of meadows, pastures and forests has increased whereas there has been a significant, more than a double increase in built-up areas. The observed changes show that this area is under the pressure of urbanization.

In the last twenty years there have been irregular changes in the land cover caused by the separation of new construction sites in individual communes located in PZLP and its buffer zone. Since the late 1990s the most buildings have appeared in the communes located in Poznań County due to the influence of the big city on the scale and rate of urbanization processes.

The analysis of the Studies of the Conditions and Directions of the Spatial Management of the communes located in the Park and its buffer zone showed the continuation of current spatial development trends, i.e. a slight increase in the forest area and an intensive growth of built-up areas at the expense of farmland. These changes are irregularly distributed around the area of six communes located in the Park and its buffer zone. It shows that individual local governments have different approaches to natural and spatial resources in their spatial policies.

The so-far collected materials suggest that further investigation into the pressure of urbanisation processes on protected areas is needed. Therefore, extending the research to other protected areas is recommended. Another prospect for further research is also to investigate the influence of local planning documents over landscape protection. Monitoring changes in the use of protected areas is also an important task for the future. Following existing trends in spatial development gives the opportunity to correct municipal spatial policy before it leads to irreversible losses of environmental and landscape resources. It would also be useful to follow trends in spatial development of the larger number of protected areas.

\section{REFERENCES}

[1] Atmis, E. (2018): A critical review of the (potentially) negative impacts of current protected area policies on the nature conservation of forests in Turkey. - Land Use Policy 70: 675-684.

[2] Bicknell, J. E., Collins, M. B., Pickles, R. S., McCann, N. P., Bernard, C. R., Fernandes, D. J., Davies, Z. G. (2017): Designing protected area networks that translate international conservation commitments into national action. - Biological Conservation 214: 168-175. 
[3] Border, J. A., Newson, S. E., White, D. C., Gillings, S. (2017): Predicting the likely impact of urbanisation on bat populations using citizen science data, a case study for Norfolk, UK. - Landscape and Urban Planning 162: 44-55.

[4] Bradshaw, C. J. (2012): Little left to lose: deforestation and forest degradation in Australia since European colonization. - Journal of Plant Ecology 5(1): 109-120.

[5] Closset-Kopp, P D., Wasof, S., Decocq, G. (2016): Using process-based indicator species to evaluate ecological corridors in fragmented landscapes. - Biological Conservation 201: $152-159$.

[6] Dimitrakopoulos, P. G., Jones, N., Iosifides, T., Florokapi, I., Lasda, O., Paliouras; F., Evangelinos, K. I. (2010): Local attitudes on protected areas: Evidence from three Natura 2000 wetland sites in Greece. - Journal of Environmental Management 91(9): 1847-1854.

[7] Environmental Protection Plan for the Commune of Czerwonak 2013-2016 with Possible Extension until 2020 (update). (2013). [In Polish].

[8] Fardila, D., Kelly, L. T., Moore, J. L., McCarthy, M. A. (2017): A systematic review reveals changes in where and how we have studied habitat loss and fragmentation over 20 years. - Biological Conservation 212: 130-138.

[9] Fletcher, R. J., Didham, R. K., Banks-Leite, C., Barlow, J., Ewers, R. M., Rosindell, J., Melo, F. P. (2018): Is habitat fragmentation good for biodiversity? - Biological Conservation 226: 9-15s.

[10] Gałecka-Drozda, A., Raszeja, E., Szczepańska, M., Wilkaniec, A. (2019): An analysis of Land Use Changes in Natura 2000 Areas Located in Suburban Zones - Planning Problems in the Context of Environmental Protection. - Polish Journal Polish Journal of Environmental Studies 28(2): 587-595.

[11] Geldmann, J., Coad L., Barnes, M., Craigie, I. D., Hockings, M., Knights, K., Leverington, F., Cuadros, I. C., Zamora, C., Woodley, S., Burgess, N. D. (2015): Changes in protected area management effectiveness over time: a global analysis. Biological Conservation 191: 692-699.

[12] Gonzalez, A., Thompson, P., Loreau, M. (2017): Spatial ecological networks: planning for sustainability in the long-term. - Current opinion in environmental sustainability 29: 187-197.

[13] Grochowska, A. (2015): Zagrożenia i konflikty w zakresie zagospodarowania przestrzennego na terenie Parku Krajobrazowego Sudetów Wałbrzyskich. - Prace Naukowe Uniwersytetu Ekonomicznego we Wrocławiu 391: 147-155.

[14] Hamer, A. J., McDonnell, M. J. (2008): Amphibian ecology and conservation in the urbanising world: a review. - Biological conservation 141(10): 2432-2449.

[15] Krajewski, P. (2014): Problemy planistyczne na terenach parków krajobrazowych w sąsiedztwie Wrocławia na przykładzie Ślężańskiego Parku Krajobrazowego. - Prace Naukowe Uniwersytetu Ekonomicznego we Wrocławiu 367: 147-154.

[16] Lima, E. A. C. F., Ranieri, V. E. L. (2018): Land use planning around protected areas: Case studies in four state parks in the Atlantic forest region of southeastern Brazil. - Land Use Policy 71: 453-458.

[17] Lopez-Bao, J. V., Chapron, G., Treves, A. (2017): The Achilles heel of participatory conservation. - Biological Conservation 212: 139-143.

[18] Maheshwari, B., Bristow, K. L. (2016): Peri-urban water, agriculture and urbanisation. Agricultural Water Management 176: 263-265.

[19] McDonald, R. I., Forman, R. T., Kareiva, P., Neugarten, R., Salzer, D., Fisher, R. J. (2009): Urban effects, distance, and protected areas in an urbanizing world. - Landscape and Urban Planning 93(1): 63-75.

[20] Muchová, Z., Tárníková, M. (2018): Land cover change and its influence on the assessment of the ecological stability. - Applied Ecology and Environmental Research 16: $2169-2182$.

[21] Nature Conservation Act of 16 April 2004 (2004): Official Journal No. 92 Pos. 880 with amendments. [In Polish]. 
[22] Puszcza Zielonka Landscape Park Protection Plan. (2005): Regulation of the Voivode of Greater Poland. - Voivodeship No. 4/05 of 4 April 2005. [In Polish].

[23] Raszka, B. (2010): Identyfikacja konfliktów przestrzennych w parku krajobrazowym Puszcza Zielonka pod Poznaniem. - Zeszyty Naukowe Południowo-Wschodniego Oddziału Polskiego Towarzystwa Inżynierii Ekologicznej z siedzibą w Rzeszowie 12: 101-106.

[24] Shwartz, A., Davies, Z. G., MacGregor, N. A., Crick, H. Q., Clarke, D., Eigenbrod, F., Gonner, C., Hill, C. T., Knight, A. T., Metcalfe, K., Osborne, P. E., Phalan, B., Smith, R. J. (2017): Scaling up from protected areas in England: The value of establishing large conservation areas. - Biological conservation 212: 279-287.

[25] Study of the Conditions and Directions of the Spatial Management of the Commune of Czerwonak (2000): Commune Council Resolution No. 173/XXVIII/2000 of 14 June 2000 [Commune of Czerwonak planning document - manuscript in Polish] http://pbip.czerwonak.pl/indexf3e.html?id=100502.

[26] Study of the Conditions and Directions of the Spatial Management of the Commune of Czerwonak (with amendments) (2010): Commune Council Resolution No. 406/LVII/2010 of 16 September 2010 [Commune of Czerwonak planning document manuscript in Polish] http://pbip.czerwonak.pl/index3e6c.html?id=94332.

[27] Study of the Conditions and Directions of the Spatial Management of the Commune of Kiszkowo (2012): Volume I Conditions. Volume II Trends. Commune Council Resolution No. XXI/167/12 of 6 November 2012 [Commune of Kiszkowo planning document - in Polish] http//kiszkowo.nowoczesnagmina.pl/?c=871.

[28] Study of the Conditions and Directions of the Spatial Management of the Commune of Murowana Goślina (with amendments) (2012): Volume I Conditions. Volume II Trends. Commune Council Resolution No. XX/196/2012 of 25 September 2012 [Commune of Murowana Goślina planning document - manuscript in Polish] http://bip.murowanagoslina.pl/wiadomosci/9836/wiadomosc/343161/studium_uwarunkowan_i_kierunkow_za gospodarowania_przestrzennego_.

[29] Study of the Conditions and Directions of the Spatial Management of the Commune of Pobiedziska (2011): Commune Council Resolution No. V/40/2011 of 24 February 2011 [Commune of Pobiedziska planning document. - in Polish] http://www.bip.pobiedziska.pl/asp/pl_start.asp?podmiot=\&strona=14\&typ=podmenu\&m enu $=161 \&$ id $=164 \&$ str $=1 \& \mathrm{~m} 1=161 \& \mathrm{~m} 2=164 \& \mathrm{~m} 3=$.

[30] Study of the Conditions and Directions of the Spatial Management of the Commune of Skoki (2010): Volume I Conditions. Volume II Trends. Commune Council Resolution No. XLVI/279/10 of 24 June 2010 [Commune of Skoki planning document - manuscript in Polish] http://skoki.nowoczesnagmina.pl/?c=923.

[31] Study of the Conditions and Directions of the Spatial Management of the Commune of Swarzędz (2011): Volume I Conditions. Volume II Trends. Commune Council Resolution No. 2011/51 of 22 November 2011 [Commune of Swarzędz planning document - manuscript in Polish] http://bip.swarzedz.eu/index.php?id=198.

[32] Szulczewska, B. (2004): Planowanie przestrzenne jako instrument realizacji sieci ekologicznych: między teorią a praktyką. - Problemy Ekologii Krajobrazu 14(14): 54-62.

[33] Treby, D. L., Castley, J. G. (2016): The impacts of historical land-use and landscape variables on hollow-bearing trees along an urbanisation gradient. - Urban forestry \& urban greening 15: 190-199.

[34] Warczewska, B., Mastalska-Cetera, B. (2011): Realizacja celów zrównoważonego rozwoju a konflikty w gospodarce przestrzennej (przykład Parku Krajobrazowego „Dolina Baryczy”) Implementation of Purposes of Sustainable Development against Clashes in Physical Planning on the Example of the Natural Landscape Park "Dolina Baryczy". - Studia KPZK 142: 196-205.

[35] Weaver, D. B., Lawton, L. J. (2017): A new visitation paradigm for protected areas. Tourism Management 60: 140-146. 
[36] Wycichowska, B. (2008): Zawłaszczanie chronionego krajobrazu kulturowego przez samorządy gminne. Bilans strat na przykładzie Parku Krajobrazowego Wzniesień Łódzkich. - Prace Komisji Krajobrazu Kulturowego PTG 10: 368-376.

[37] Xun, B., Yu, D., Wang, X. (2017): Prioritizing habitat conservation outside protected areas in rapidly urbanizing landscapes: A patch network approach. - Landscape and Urban Planning 157: 532-541.

[38] Yang, H., Chen, W., Chen, X. (2017): Regional Ecological Network Planning for Biodiversity Conservation: A Case Study of China's Poyang Lake Eco-Economic Region. - Polish Journal of Environmental Studies 26(4): 1825-1833.

[39] Zhang, X. Q. (2016): The trends, promises and challenges of urbanisation in the world. Habitat International 54: 241-252. 